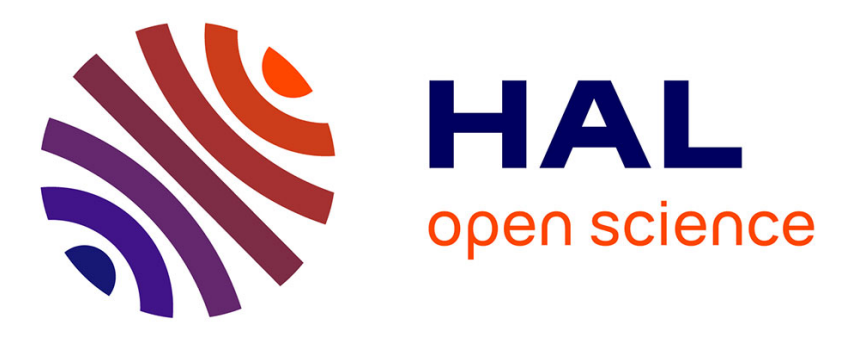

\title{
Andrew Fisher: Big Hunger. The Unholy Alliance between Corporate America and Anti-Hunger Groups Cambridge MA, MIT Press, 2017, 343 p.
} Graham Riches

\section{- To cite this version:}

Graham Riches. Andrew Fisher: Big Hunger. The Unholy Alliance between Corporate America and Anti-Hunger Groups Cambridge MA, MIT Press, 2017, 343 p.. Review of Agricultural, Food and Environmental Studies, 2018, 99 (2), pp.207-210. 10.1007/s41130-018-0072-y . hal-03114859

\author{
HAL Id: hal-03114859 \\ https://hal.science/hal-03114859
}

Submitted on 19 Jan 2021

HAL is a multi-disciplinary open access archive for the deposit and dissemination of scientific research documents, whether they are published or not. The documents may come from teaching and research institutions in France or abroad, or from public or private research centers.
L'archive ouverte pluridisciplinaire HAL, est destinée au dépôt et à la diffusion de documents scientifiques de niveau recherche, publiés ou non, émanant des établissements d'enseignement et de recherche français ou étrangers, des laboratoires publics ou privés. 


\title{
Andrew Fisher: Big Hunger. The Unholy Alliance between Corporate America and Anti-Hunger Groups Cambridge MA, MIT Press, 2017, 343 p.
}

\author{
Graham Riches ${ }^{1}$
}

Published online: 30 May 2018

(C) INRA and Springer-Verlag France SAS, part of Springer Nature 2018

Against a backdrop of persistent and widespread food insecurity in the USA (14\% of the population in 2016), Big Hunger is an original, informative and timely book. It critically explores anti-hunger organizations' deep links with Corporate America: the national corporate capture of charitable food banking by Big Ag and Big Food-the industrial agri-food/retail sector - epitomized by Feeding America; and the role of the United States Department of Agriculture (USDA) with its significant array of federal food assistance and nutrition services. It investigates the causes, consequences and 'collateral damage' of such an 'unholy alliance' asking who benefits and why from addressing food insecurity in this way. Rather than continually 'feeding the need' Big Hunger's analysis leads to recommendations for re-making the Anti-Hunger movement as a force for food justice across the USA through promoting and advocating for economic democracy.

Big Hunger is written from an insider's food system's perspective and commitments. It is well written, well researched and designed for public readership. It draws on author Andy Fisher's knowledge, experience and insights with years of direct practice and influencing US food policy as co-founder and leader of the Community Food Security Coalition (1994-2011), a national alliance of groups working on food access and local food. This adds to the book's authenticity and sense of immediacy. It is very much the voice of the policy advocate informed by the relevant literature, interviews with key players and with an intimate and detailed knowledge of how the charitable (or not so charitable) Anti-Hunger movement and the public 'emergency food system' work (or do not) to advance food security and what are alternative course of action.

The book considers the rediscovery of hunger and poverty in the late 1960s in the USA, with roots in the Great Depression, and how the idea of hunger has become embedded in American culture acting as a motivational and mobilizing force for

Graham Riches

Graham.Riches@ubc.ca

1 University of British Columbia, Vancouver, Canada 
charitable food banking and public food assistance programs (e.g., SNAP, school lunch programs). It offers a necessary and provocative critique of Anti-Hunger groups allowing the public, and themselves, to believe that hunger can be solved both through corporate charity and the federal 'emergency food system'. As Fisher contends, this is problematic given the structural roots of hunger lie in poverty with inadequate attention to race, class, income inequality and, one might add, gender. As such Big Hunger is an exposé of the power and workings of the US Anti-Hunger-Industrial Food Complex, why and how this has come about including recommendations for change.

The book is both balanced and committed with case studies illustrating central themes. Competing arguments are well documented and referenced including numerous quotes from key players with success acknowledged when due. Set in a historical context Fisher investigates the dilemmas and contradictions facing the US Anti-Hunger movement in seeking to reduce widespread food insecurity (hunger and obesity). Two themes central to Big Hunger's analysis merit attention: the institutionalization and politics of corporate food banking in America and economic democracy as the alternative course of action.

Certainly, food charity's dependence upon Big Ag and Big Food, financial, transportation and legal corporate partners, celebrity endorsement and the media is a clear marker not only of 'an unholy alliance' fed by an idea of corporate social responsibility (or branding and corporate social investment) but of the power and politics of philanthrocapitalism. Leave domestic hunger to the market and 'effective altruism'.

Yet corporate food banking remains a small player compared to the $\$ 100$ billion dollars spent annually on domestic US federal food aid programs. Ever present community food drives and gala events with their constant appeals for food and financial donations allow the public to believe that home grown hunger is being solved. Inevitably, the deeper problems of poverty and inequality are masked when the answer to food insecurity is donating surplus food (edible food waste) and not income distribution and 'joined-up' public policy. Ironically, the 2017 DuPont Global Food Insecurity Index ranks the USA, trailing Ireland, as the second most food secure country in the world. Maybe in terms of food production, but hard to believe when more than 40 million Americans cannot afford to put food on the table.

Fisher recognizes that continually handing out more and more food parcels ('feeding the need') is not the answer to widespread food insecurity particularly as it diverts the attention of anti-hunger and food policy NGOs from tackling root causes. He would like to use the USDA's $\$ 100$ billion food aid expenditure to sow the seeds of economic democracy as the path ahead. Drawing on ideas from the 2015 Closing the Hunger Gap Conference attended by a wide array of food bank and community food organization staff, volunteers and advocates, he sets out a number of innovative approaches being developed by the Anti-Hunger movement. These include putting a cap on the amount of food being distributed; advocating for short-term funding for emergency food aid whilst addressing longer term solutions such as advancing public policies to 'increase the living standards of the working poor: a higher state minimum wage; affordable housing, health care, creation of living wage jobs, accessible child care and expanded public assistance benefits'; raising race and class awareness; supporting farming and gardening operations which build community food security, healthy eating and nutrition education; job training; addressing the issue of food deserts; promoting economic development, job skills and employment. It is a case of building solidarity and understanding justice, not food as the answer to hunger. 
He also looks outside the anti-hunger movement for innovative ideas and actions. These include focusing on how Anti-Hunger groups do their work stressing the importance of empowering grassroots leadership and by evaluating food charity or public food aid not by the volume of food distributed or school meals provided but by increased access to healthy food, nutrition education and reduced rates of childhood obesity. In other words, looking at outcomes not inputs. Increasing the incomes of those working in the corporate food sector to prevent them from becoming dependent on emergency food aid and building the wealth of low income persons are likewise priorities. Fisher emphasizes holding the corporate food sector publicly to account 'so that they do treat their workers and suppliers with respect and dignity and stop externalizing their labor costs onto the public'.

'Respect and dignity' bring the issue of domestic hunger in the wealthy, 'food secure' and powerful USA (and indeed across all OECD countries) to the matter of food as a basic human need and fundamental human right. Whilst open to a human rights — right to food-analysis, Fisher argues this has few legs in the USA (as elsewhere in much of the rich world). He does, however provide a clear exposition of the right to food noting its origins in the Universal Declaration of Human Rights (1948) and the International Covenant on Economic, Social and Cultural Rights (1966) since ratified by all wealthy UN member states excluding, as Fisher notes, the USA. As a consequence of ratification attention is drawn to the obligations of member states under international law to 'respect, protect and fulfill' the right to food. It should also be noted the state is the 'primary duty bearer' for ensuring its citizens are free from hunger and for the progressive realization of food security for all. This is not about government doing everything. Indeed as Big Hunger makes clear there are crucial roles for the corporate sector and civil society. Yet government is in charge and democratically accountable.

The right to food is not about giving away free food to hungry people (though surely the moral imperative is clear). Rather, it is about the right of everyone to feed themselves and their families with choice and human dignity. In a market economy, this implies having enough money in your pocket to shop for food like everyone else. Begging and reliance on charity is not an option.

Certainly, as Fisher writes the 'goals of economic justice, healthy individuals and a democratic food system create a three legged stool on which an integrated and successful anti-hunger field sits', and one can ill afford for one of the legs to topple undermining the capacity to 'fully address food insecurity'. Yet, the role of government and public policy is the lynchpin for the reduction and solving of the domestic hunger problem. Food transfers - whether charitable or public - can hardly be an adequate response to the structural issues of hunger and poverty when inadequate incomes and social security transfers hold millions below the poverty line. The answer must surely lie in 'joined-up' public policy: income, food, affordable housing, public health, accessible child care and social policy.

Big Hunger provides an informed food policy insider's analysis of charitable food banking of the Anti-Hunger-Industrial Food Complex in the USA. As such it makes a significant contribution to the growing international literature and public debate about domestic hunger, food insecurity, corporate food charity, food waste, surplus food redistribution and the neglected right to food in rich societies in today's badly fractured and failing welfare states. 
In asking who benefits and why from the symbiotic relationships between corporate food market power, food banking, the Anti-Hunger movement and the state necessary and urgent questions are raised both within the USA and all rich world countries consumed by three decades of neo-liberal austerity driven food poverty. Given the alarmingly high prevalence and persistence of hunger and food insecurity in the USA and the export of its corporate brand of charitable food banking and public food aid across the OECD the searchlight should focus on human rights, public policy and state accountability. Why the drift away from European style income distribution and social security as the bedrock of welfare state provision to ineffective programs of food distribution and from a right to food perspective the morally challenged model of corporate charity?

Big Hunger should be read by different audiences: staff, volunteers, activists and advocates within food bank, food policy and food justice organizations; executives in the multinational corporate food sector; policy makers within the state bureaucracies responsible for food, health, the environment and social policy; those dependent on food charity; and the general public. It is essential reading for academics and students of food policy, environmental studies, public health, social policy, social work, community planning, law and human rights. 